Review Article

\title{
Review of Sensor Network-Based Irrigation Systems Using IoT and Remote Sensing
}

\author{
Wei Li $\left(\mathbb{D},{ }^{1}\right.$ Muhammad Awais $\left(\mathbb{D},{ }^{1}\right.$ Weimin Ru, ${ }^{1}$ Weidong Shi ${ }^{1},{ }^{2}$ Muhammad Ajmal, ${ }^{3}$ \\ Saad Uddin, ${ }^{4}$ and Chenchen Liu ${ }^{1}$ \\ ${ }^{1}$ Research Center of Fluid Machinery Engineering \& Technology, Jiangsu University, Zhenjiang, China \\ ${ }^{2}$ College of Mechanical Engineering, Nantong University, Nantong 226019, China \\ ${ }^{3}$ School of Agricultural Equipment Engineering, Jiangsu University, Zhenjiang, China \\ ${ }^{4}$ School of Mechanical Engineering, Jiangsu University, Zhenjiang, China
}

Correspondence should be addressed to Wei Li; lwjiangda@ujs.edu.cn

Received 22 September 2019; Revised 17 March 2020; Accepted 6 August 2020; Published 7 September 2020

Academic Editor: Nir Y. Krakauer

Copyright $\odot 2020$ Wei Li et al. This is an open access article distributed under the Creative Commons Attribution License, which permits unrestricted use, distribution, and reproduction in any medium, provided the original work is properly cited.

\begin{abstract}
The motivation for this review paper came from the developing countries where the economy is mostly dependent on agriculture and climate conditions. Based on current conditions and historical records, profitability in production farming depends on making a right and timely operational decision. Precision farming is a systematic program designed to maximize the productivity of agriculture by carefully tailoring the soil and crop management to meet the specific requirements in each field while preserving environmental quality. This review paper highlights the development of an automated irrigation system with portable wireless sensor networks and decision support methods to remotely measure the environmental parameters in an agriculture field. Radio satellite, mobile phones, sensors, internet-based communication, and microcontroller capture the ecological parameters such as soil moisture, temperature, humidity, and light intensity. The knowledge gained from the sensors is transferred directly to the cloud server by using IoT technology. Users from anywhere in the world can display them through an internet-enabled device. Development of sensor-based application in modern agriculture makes it cost-effective and potentially productive and increases the efficiency through precision agriculture farming. Different limitations have been reported in the previously reviewed publications like the shortage of power in the field that can be solved by using a solar panel that recharges the battery at the same time using electricity. Bluetooth application in the agriculture sector is mainly improved by design system optimization. Problems related to transmission and radio range frequency can be solved by using a power class upgraded antenna.
\end{abstract}

\section{Introduction}

Human civilization around the globe is preparing for a population explosion to hit a total of 10 billion inhabitants by 2050 (United Nations, 2017). It has been estimated that global food production must increase by least $70 \%$ over the coming years to keep pace with this growth [1-3]. Over the years, agricultural methods have not improved much, and farmers still use conventional strategies based on expectations of the crop's nutritional needs. Delivering the same nutrient input across the entire farm is no longer the best choice, as this leads to heavy fertilizer and pesticide usage, unnecessary water consumption, environmental degradation, and high operating costs $[4,5]$. Extensive irrigation consumes approximately $70 \%$ of global water [6]. The industrial and domestic sectors account for $13 \%$ and $20 \%$, respectively, although this variation in percentage is considerable variation across countries. According to the Act 1947, it defines agriculture, including livestock's breeding, dairy farming, horticulture, seed growing, and fruit growing [7]. Agriculture aims to utilize maximum land and increase the profit. The agricultural sector needs to adopt smarter methods of farming. Innovative techniques in agriculture, such as precision farming techniques, help with these concerns. Precision farming is a farm management method that uses information technology to efficiently distribute resources and ensure that 
the crops and soil receive the exact nutrients needed at the perfect time for enhanced health and productivity [8]. In recent years, the researchers have tried to develop automated control irrigation systems for irrigation management by using cloud computing and IoT technology; IoT can be characterized as a network of independent objects that link and share data remotely over the Internet $[9,10]$. The gap between supply and demand is rising and sets new challenges adding pressure on the agriculture supply chain [11]. Traditionally available techniques for irrigation are drip irrigation, ditch irrigation, sprinkler systems, and terraced systems. The standard irrigation practices are classified by demand increase for productivity, shortage of water, and poor performance for agriculture practice. These problems are solved by using automated irrigation systems.

\subsection{Need for Automatic Irrigation}

(i) Saving energy and resources for utilizing in a precise way.

(ii) Easily installation of the system on the field.

(iii) To apply the right amount of water at the right time for the sake of farmer's easiness to control farm irrigation and nursery.

(iv) Valves are used in automated irrigation systems to turn on/off the motor.

(v) Pump or motor can be easily operated with a sensorbased controller and no need for any labor to manage or monitor irrigation systems. Crop efficiency includes improvement in the reduction of the overwatering from the saturated soil and avoiding the wrong time of irrigation to save more water.

A significant part of freshwater is consumed in the agricultural sector due to the unavailability of cost-effective irrigation systems [12-14]. Fortunately, previous implementations of agricultural monitoring systems for irrigation practices were riddled with problems that prevented the progress of this sector. Previously, farm surveillance systems comprised of a wired data collection system in which a data transmission linked the sensor units with monitoring stations $[13,15,16]$. Rainfall and evapotranspiration is an important factor which influences the moisture of the soil in climatology and geography soil wetness measured by the proportion of monthly (or annual) evaporation and precipitation. Soil moisture daily can also be calculated by the ratio of daily evaporation and precipitation in the above perspective from the routine weather reports precipitation is directly accessible, and evaporation is derived from other metrological essentials [17]. Heterogeneous systems are used to gather information at a higher level; smart algorithms can be organized for evaluating scientific knowledge to provide an enhanced understanding of the ongoing processes $[18,19]$. For sensors-based irrigation, different terminologies are used, i.e., Precision Farming, Variable Rate Technology (VRT), Smart Agriculture, Global Positioning Service (GPS), and Site-Specific Crop Management. [20]. Nowadays, sensors can be used in the domain of human life due to its modern technology and small size. Due to the consequence of this technology, numerous problems associated with sensor networking are in research. Low memory, energy constraint, and data security are some of the significant issues of sensor networks in which different researchers in the world are trying to solve these issues [21, 22]. This review is proposed to support aggressive water management for agricultural land. It aims to explain the different modern and sensor-based irrigation management techniques and track environmental parameters in the field of agriculture and provide warnings and information on current conditions to field managers while saving data for future reference in a database, which includes information collecting using remote sensor collection, wireless sensor network, target controlling, and data management scheme as shown in Figure 1. This review paper is based on sensorbased irrigation systems and modern technologies in the previous works; this study will be helpful to new researchers in this field to get more knowledge and provide more up to date and fill the gap through this review study.

\section{Related Work}

An automatic sprinkler is a new irrigation technique of modern agriculture, but until now, it is not entirely accepted among the farmers. Mostly, it is practiced by the researchers for performing the experimental studies. Wireless sensor network (WSN) is conceived as a new concept in agricultural applies, which encouraged many scholars to accomplish research in this zone. Recent developments in wireless sensor network (WSN) technologies have enabled wired sensor systems to solve specific problems [23-26]. Recent developments in wireless sensor network (WSN) technologies have enabled wired sensor systems to solve particular problems [27-29]. This segment is mainly focusing on how different researchers used WSN systems to support agricultural practices and irrigation. Abbas et al. have developed a smart sensor-based system for parks and gardens that make use of different modern sensors. In this system, the latest soil moisture sensors are used to sense the field moisture as well as different soil characteristics such as water holding capacity [30]. The main aim of this system is to calculate the time that is taken by the sensors to get activated and distinguished the irrigation zone. ZigBee is used to make a connection between sensor nodes and wireless-based stations. This system has four significant portions, i.e., control unit, water controller, security systems, and mobile messaging unit [31]. The primary function of the water controller is to identify the level of water in the field and to represent the microcontroller. Output functions of water sensors are to switch the microcontrollers and automatically turn on or turn off the pump mechanism. If the farm is submerged, then the controller is automatically turned on the pump that takes out additional water from the field. Security systems and password protection were used to control unit and pumps from unauthorized access. Water is being applied through proper network systems that involve pipes, pumps, valves, and sprinklers. Irrigation sprinklers can also be used for industrial, commercial, residential, and 


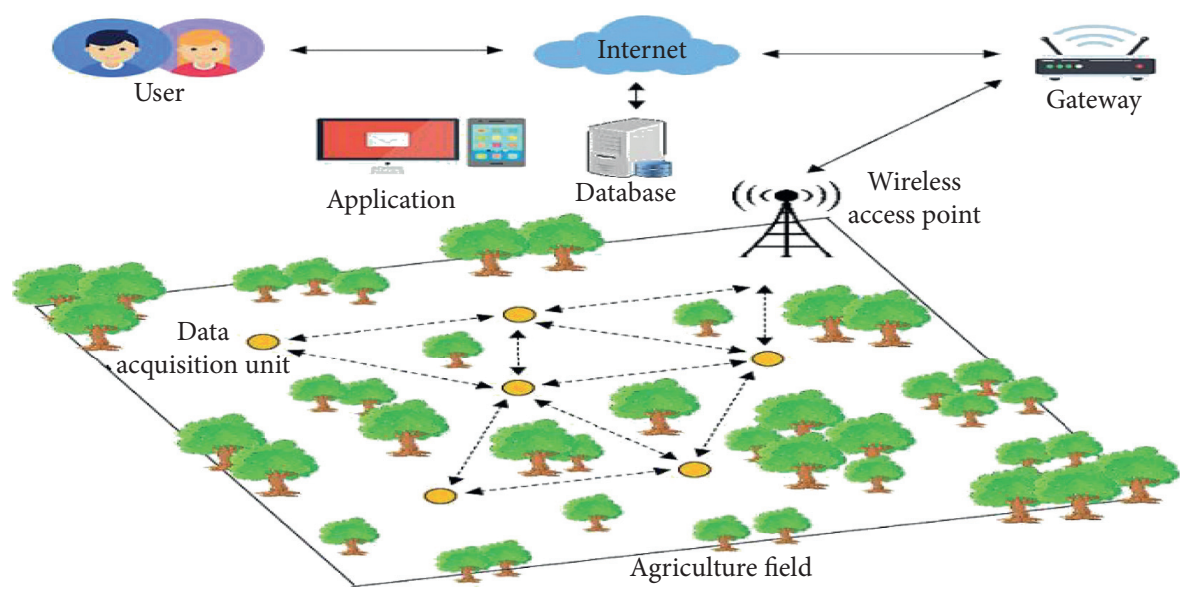

FIGURE 1: Wireless sensor network layout for the automated irrigation system.

agricultural purposes. Moreover, several studies considered sensor-based irrigation is a modern-day irrigation activity that is practiced in a large area under entire controlledconditions, as it could eliminate the external environmental factors compared with the traditional irrigation activities. The GSM sensor-based irrigation control system with a gun sprinkler was declared in [32-34] with rain gun systems operated with the automatic microcontroller for crops requiring a more significant amount of water in the field. Cell phone applications play a fundamental part in the multiple needs of humans. GPRS feature in the mobile phone application is used for irrigation control systems, but these systems are not economical and cover less range of agricultural land. The methods used GSM feature and the android app for sending a message to farmers and notify them about overirrigation and under irrigation that causes losses, leaching the nutrient content of soil $[35,36]$. Satellite communication schemes are widely used or prefer where topography difference is significant, and cell phone service is not reachable $[37,38]$. Radio systems with certified power (e.g., 5-10 W) with modems are also a good option but affected by topographic hindrance. For radiofrequency, repeater stations may become too costly when there is communication over a significant distance and different topography. The central aspect of this technology is to develop decision support systems based on field-specific information that exploits the chemical or applied water concentration [39]. Lamb et al. developed a system which is operated by photovoltaic irrigation to enhance water depletion by using temperature sensors and moisture sensors [40].

2.1. Soil Evaporation Model [41, 42]. For proper irrigation management, prediction of soil moisture plays a vital role. The Penmen method was considered to get the possible accurate results with a minimum error related with living grass reference crop. It was observed that the pan method would give us acceptable accuracy dependent on the position of the land. The FAO Penman-Monteith method to measure $\mathrm{ET}_{0}$ is shown in the following equations:

$$
\begin{aligned}
\mathrm{ET}_{0} & =\frac{0.408 \Delta(\mathrm{Rn}-G)+\gamma(900 /(T+273)) \mu_{2}(\mathrm{ex}-e \alpha)}{\Delta+\gamma(1+0.34 \mu 2)}, \\
\Delta & =\frac{4098[(0.6108) \exp (17.27 T /(T+273))]}{(T+273.3)^{2}}, \\
\frac{C_{P}}{e^{0}}(P) & =0.665 \times(10)^{-3}, \\
P & =101.3\left(\frac{293-0.0065 z}{293}\right)^{5.62}, \\
E 0(T) & =(0.6108) \exp \left(\frac{17.27 T}{T+273.3}\right)
\end{aligned}
$$

where $\mathrm{ET}_{0}=$ reference evapotranspiration $\left(\mathrm{mm} \mathrm{day}{ }^{-1}\right)$, $G=$ heat flux density of soil $\left[\mathrm{MJ} \mathrm{m}^{-2} \cdot\right.$ day $\left.^{-1}\right], \mu_{2}=$ wind speed

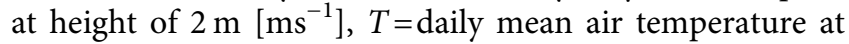
$3 \mathrm{~m}$ height $\left[{ }^{\circ} \mathrm{C}\right], \mathrm{Rn}=$ crop surface net radiation $[\mathrm{MJ}$ $\mathrm{M}^{-2}$ day $\left.{ }^{-1}\right]$, ea $=$ actual vapor pressure $[\mathrm{kPa}]$, es $=$ saturated vapor pressure $[\mathrm{kPa}]$, es-ea $=$ deficit saturation vapors pressure $[\mathrm{kPa}], P=$ atmospheric pressure $[\mathrm{kPa}], \Delta=$ curve of slope vapor pressure $\left[\mathrm{kPa}^{\circ} \mathrm{C}^{-1}\right], \gamma=$ psychrometric constant $\left[\mathrm{kPa}{ }^{\circ} \mathrm{C}^{-1}\right], z=$ elevation above sea level $[\mathrm{m}], e^{0}(\mathrm{~T})=$ saturation vapor pressure at the air temperature $T[\mathrm{kPa}]$, $C_{P}=$ specific heat at constant pressure, $1.01310^{-3}[\mathrm{MJ}$ $\left.\mathrm{kg}^{-10} \mathrm{C}^{-1}\right], \lambda=$ latent heat of vaporization, $2.45\left[\mathrm{MJ} \mathrm{kg}^{-1}\right]$, $€=$ ration molecular weight of water vapor/day air $=0.622$.

The soil moisture estimation is mainly depending upon the evapotranspiration. The other most frequently used method based on extraterrestrial radioactivity and temperature to evaluate $\mathrm{ET}_{0}[43]$ :

$$
\mathrm{ET}_{0}=0.0023 \mathrm{Ra}\left(\frac{T_{\max }+T_{\min }}{2}+17.8\right) \sqrt{T_{\max }+T_{\min }},
$$

where $\mathrm{ET}_{0}=$ reference evapotranspiration $(\mathrm{mm} /$ day $), T_{\max }$ and $T_{\min }=\max$. temperature and min. temperature $\left({ }^{\circ} \mathrm{C}\right)$, $\mathrm{Ra}=$ extraterrestrial radiation $\left(\mathrm{MJ}^{\mathrm{m}-2} \mathrm{day}^{-1}\right)$. 
Ritchie purposed another method for the estimation of $\mathrm{ET}_{0}$ [44] based on solar radiation and temperature. It is expressed as

$$
\mathrm{ET}_{0}=1\left[3.87 \times 103 \mathrm{Rs}\left(0.6 T_{\max }+0.4 T_{\min }+29\right)\right],
$$

where $\mathrm{ET}_{0}=$ reference evapotranspiration $\left(\mathrm{mm} /\right.$ day); $T_{\max }$ and $T_{\min }=$ maximum and minimum temperature $\left({ }^{\circ} \mathrm{C}\right)$; and $\mathrm{Rs}=$ solar radiation $\left(\mathrm{MJm}^{-2} \mathrm{day}^{-1}\right)$.

When

$$
\begin{array}{ll}
5<T_{\max } \leq 35^{\circ} \mathrm{C}, & \alpha=1.1, \\
T_{\text {max }}>35^{\circ} \mathrm{C}, & \alpha=1.1+0.05\left(T_{\text {max }}-35\right), \\
T_{\text {max }}<{ }^{\circ} \mathrm{C}, & \alpha=0.01 \mathrm{EXP}\left[0.18\left(T_{\max }-5\right)\right] .
\end{array}
$$

An evapotranspiration measurement method was established on neurofuzzy (NF) inference and originated that the NF model (depended on relative humidity, solar radioactivity, and air temperature) shows better precision over the combination of air temperature, wind speed, and solar radiation [45]. Soil moisture has been predicted from the weather forecast sensors placed at the farm. The soil moisture evaporation depends on air relative humidity, air temperature, radiation, and temperature of the soil [46]. A sensor-based and IoT constructed architecture (Figure 2) has been developed for collecting, processing, and transmitting the different physical parameters (air temperature, air relative humidity, soil moisture soil temperature, and radiation) of the farmland related to weather forecast information for making efficient irrigation.

The system comprises two main components, i.e., Wireless Information Unit (WIU) and Wireless Sensor Unit (WSU). The sensor units have different types of sensors to sense the soil temperature and soil moisture, and the main microcontroller received sensed data and optimized it. ZigBee is used to send data to WIU. Such WSN networks also added a small transmission spectrum and high network costs [47-49]. Data acquisition structures are developed to be used in environmental compliance along with greenhouses or food factories and lack of solidity to be used outside for prolonged periods. Vishwakarma and Choudhary developed another option for irrigation systems operated with SMS facilities, and farmers received a text to mobile phones. This system incessantly observes the irrigation pump and electric motor and aware the farmers by sending an SMS to the mobile telephone representing the accessibility of power supply to the motor. The farmer selects to turn off and on the electric motor by sending an SMS to the sensor-based systems that are installed on the field, and networks can act according to the programming command as received in SMS; the farmers are also able to set the timer according to their need to turn off the motor automatically [50].

\section{Remote Sensing in Modern Irrigation}

Remote sensing is the latest technique for collecting data through different satellite sensor technologies. This technique involves very close examination of vast land set images and photos that are captured by aerial photographs which are followed by an interpretation, identification, and mapping of different agricultural resources and various water data that are connected with forest, water bodies, villages, roads, crop area, soil, and land types. Throughout the agricultural field, optical or visual RS is one of the most often exploited in remote sensing. This uses various bands, i.e., NIR and SWIR sensors, to collect images from Earth surfaces by reflecting features from the surface of the target area [51]. Thermal sensors are often used to measure surface temperature and have detected rapid response variables to track crop health and crop stress $[52,53]$. Thermal remote sensing is a process of monitoring radiation emitted from the surface of the object and transmits it to temperature without creating any contact with the object. All surface objects emit radiation above the temperature of ${ }^{\circ} \mathrm{K}$ or $273^{\circ} \mathrm{C}$ [54]. The absorption intensity of each object depends on the temperature; the higher the temperature, the greater the intensity of the radiation. Thermal remote sensing provides us with substantial temperature and energy transfer from the earth's surface, which is essential to assume the processes and responses of the landscape $[55,56]$. For many agriculture application series of airborne thermal sensors, the satellite uses directly or indirectly, as shown in Table 1.

These remote sensing and agrometrological station data are very useful to improve the actual crop yield estimation and involve in the development of crop growth and yield models. Soil moisture conditions also play a vital role in both rainfed and irrigated conditions. Thus, monitoring the moisture of the soil condition status using remote sensing data would be very impressive and useful to judge the actual crop condition in advance and provide valuable suggestions to farmers for their pesticide application, water-saving irrigation, and postponding fertilizer.

3.1. Why Sensors in Sprinkler Irrigation. Sensors are used in sprinkler irrigation to get information about real-time physical and environmental characteristics, and they are also employed to acquire feedback and have regulators over the current situation. The sensors accumulated information to identify the current object, people, location, and conditions known as context $[57,58]$.

The agriculture sector carries numerous requirements through sensors that are as follows:

(i) Monitoring of distributed land

(ii) Collecting soil, crop, and weather information

(iii) Multiple crops in a signal piece of land

(iv) Fertilizer and water requirement of different irregular lands

(v) Protective solution rather than the sensitive solution

Different sensors that are mainly used to collect the data for agricultural-related practices and acquisition for soil, plant, and weather are discussed in Tables 2-4.

3.2. Use of Sensors in Modern Irrigation. Application of sensor is attractive in every field of life due to the novelty of this technology and size reduction; the ability of the sensor is 


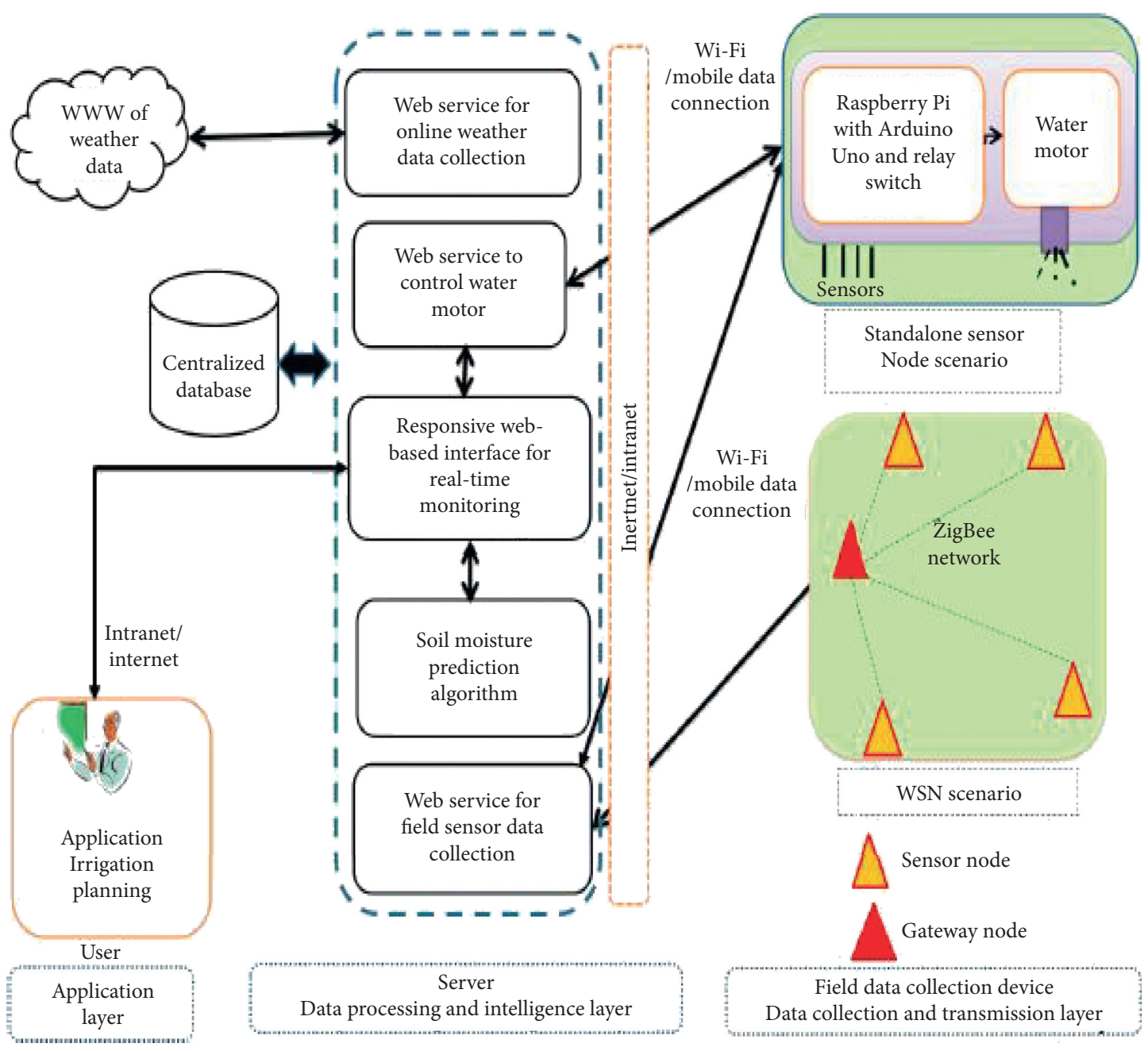

FIgURE 2: The architecture of the proposed system.

TABLE 1: Satellite and airborne thermal infrared sensors attached to platforms.

\begin{tabular}{|c|c|c|c|c|c|}
\hline Sensor satellite & Wavelength $(\mu \mathrm{m})$ & $\begin{array}{l}\text { Waveband } \\
\text { (thermal) }\end{array}$ & $\begin{array}{l}\text { Spatial resolution } \\
(\mathrm{m})\end{array}$ & $\begin{array}{c}\text { Temporal resolution } \\
\text { (days) }\end{array}$ & Reference \\
\hline MODIS & $\begin{array}{c}3.66-4.55: \\
8.4-14.80\end{array}$ & $20-25,29-35$ & 10000 & 1 & NASA (2016B) \\
\hline $\begin{array}{l}\text { AATSR/ } \\
\text { ENVISAT }\end{array}$ & $11.0-12.0$ & $6-7$ & 1000 & 1 & $\begin{array}{l}\text { Llewellyn-Jones et al. } \\
\text { (2001) }\end{array}$ \\
\hline ASTER & $8.125-11.65$ & $10-14$ & 90 & 16 & NASA (2016a) \\
\hline CBERS/Landsat & $14.4-12.5$ & 4 & 80 & 26 & CBERS (2016) \\
\hline ABI/GOES-R & $10.1-13.6$ & $13-16$ & 2000 & Hourly & GOES-R (2016) \\
\hline AVHRR & $\begin{array}{c}3.5-3.93 \\
10.50-12.5\end{array}$ & 3 & 1100 & 0.5 & NOAA (2016) \\
\hline \multicolumn{6}{|l|}{ Airborne* } \\
\hline Atlas & $8.32-12.02$ & $10-15$ & 10 & - & Lo et al. (1997) \\
\hline TIMS & $8.2-12.2$ & 6 & 50 & - & Kealy and Hook (1993) \\
\hline
\end{tabular}

${ }^{*}$ Human operated.

to measure the physical characteristics and change them in to signal for an observer. Through specific irrigation management techniques, producers can maximize their yield by saving a large amount of water. Site-specific irrigation control systems are facing many challenges nowadays in terms of designing software, unified combination of sensors, data interface, and communication protocol [59]. Solar panels and electric power are a significant consideration. Many researchers are trying to address the different issues related to irrigation control and interfacing sensors by using 
TABLE 2: Sensors used for irrigation control systems in farming domains (soil sensors).

\begin{tabular}{|c|c|c|c|c|c|c|}
\hline Sensor & Temperature & Moisture & $\begin{array}{l}\text { Dielectric/ } \\
\text { permittivity }\end{array}$ & $\begin{array}{l}\text { Rain } \\
\text { water }\end{array}$ & Conductivity & Reference \\
\hline Hydra probe II soil sensor & $\checkmark$ & $\checkmark$ & $\checkmark$ & $\checkmark$ & $\checkmark$ & http://www.stevenswater.com \\
\hline $\begin{array}{l}\text { MP406 soil moisture } \\
\text { sensor }\end{array}$ & $\checkmark$ & $\checkmark$ & $\checkmark$ & - & - & $\begin{array}{c}\text { http://www.ictinternational.com. } \\
\text { au }\end{array}$ \\
\hline EC sensor (EC25) & $\checkmark$ & $\checkmark$ & - & & - & http://www.stevenswater.com \\
\hline Pogo portable soil sensor & $\checkmark$ & $\checkmark$ & $\checkmark$ & $\checkmark$ & $\checkmark$ & http://www.stevenswater.com \\
\hline ECRN-100 high-REC rain & - & - & - & $\checkmark$ & - & http://www.decagon.com \\
\hline ECRN-50 low-REC rain & - & - & - & $\checkmark$ & - & http://www.decagon.com \\
\hline Tipping bucket rain gage & - & & - & $\checkmark-$ & - & http://www.stevenswater.com \\
\hline 107-L temperature sensor & $\checkmark$ & - & - & - & - & http://www.campbellsci.com \\
\hline
\end{tabular}

TABLE 3: Sensors used for irrigation control systems in farming domains (leaf/plant).

\begin{tabular}{lccccccc}
\hline Sensor & Photosynthesis & Moisture & Hydrogen & Temperature & Wetness $^{\mathrm{CO}_{2}}$ & Reference \\
\hline 237 leaf wetness & - & $\checkmark$ & - & $\checkmark$ & $\checkmark$ & - & http://www.campbellsci.com \\
SenseH2 & hy hydrogen & - & - & $\checkmark$ & - & - & http://www.ntmsensors.com \\
YSI 6025 chlorophyll & - & - & - & - & - & - & http://www.ysi.com \\
TT4 multisensor thermocouple & - & $\checkmark$ & - & $\checkmark$ & - & - & http://www.ictinternational.com \\
TPS-2 portable photosynthesis & $\checkmark$ & $\checkmark$ & - & $\checkmark$ & $\checkmark$ & $\checkmark$ & http://www.ppsystems.com \\
Cl-340 handheld & $\checkmark$ & $\checkmark$ & $\checkmark$ & $\checkmark$ & $\checkmark$ & $\checkmark$ & http://www.solfranc.com \\
LW100 leaf wetness & - & $\checkmark$ & - & $\checkmark$ & $\checkmark$ & - & http://www.globalws.com \\
Leaf wetness sensor & - & & - & - & - & - & http://www.decagon.com \\
Field scout (CM1000TM) & $\checkmark$ & - & - & - & - & - & http://www.specmeters.com \\
LT-2M (LTS) & - & - & - & $\checkmark$ & - & - & http://www.solfranc.com \\
\hline
\end{tabular}

TABLE 4: Sensors used for irrigation control systems in farming domains (weather).

\begin{tabular}{lcccccc}
\hline Sensor & Temperature & $\begin{array}{c}\text { Wind } \\
\text { speed }\end{array}$ & $\begin{array}{c}\text { Wind } \\
\text { direction }\end{array}$ & Humidity Atmospheric & Reference \\
\hline $\begin{array}{l}\text { Met station one } \\
\text { CM-100 compact weather sensor }\end{array}$ & $\checkmark$ & $\checkmark$ & $\checkmark$ & $\checkmark$ & $\checkmark$ & http://www.stevenswater.com \\
http://www.stevenswater.com \\
HMP4SC (Visalia's HUMICAP H- & $\checkmark$ & $\checkmark$ & $\checkmark$ & $\checkmark$ & $\checkmark$ & http://www.campbellsci.com \\
chip) & & - & - & $\checkmark$ & $\checkmark$ & http://www.sensirion.com/ \\
SHT75 (heat and temp. sensor) & $\checkmark$ & - & - & $\checkmark$ & $\checkmark$ & humidity \\
SHT71 & $\checkmark$ & - & - & $\checkmark$ & $\checkmark$ & http://www.sensirion.com \\
XFAM-115KPASR & $\checkmark$ & - & - & $\checkmark$ & $\checkmark$ & http://www.pewatron.com \\
Cl-340 handheld photosynthesis & $\checkmark$ & - & - & $\checkmark$ & - & ht//www.decagon.com \\
\hline
\end{tabular}

numerous approaches. Shen et al. developed a GSM-SMS remote autonomous control system for the greenhouse [60], which depends on PC-based dataset and linked with the base station at the same time. The component of the based station is an actuator, GSM module, sensors, and microcontroller. The GSM module plays a vital role in the base station to send and receive messages from central stations. Various techniques can be used to calculate the soil moisture (in the gravimetric and volumetric forms), which are further classified into modern and classical procedures for both laboratory and in situ measurements. The conventional techniques to calculate the moisture in soil include tensiometers methods, thermogravimetric, gypsum block, and calcium carbide neutron scattering [61]. While for modern techniques, different latest dielectric technologies and infrared moisture balance such as heat flux moisture sensors, time domain reflectometry (TDR), capacitance and optical method, frequency domain reflectometry (FDR), and microelectromechanical systems are used [62, 63]. Radio transmission wireless systems were used to transfer soil moisture data from data loggers to an essential data logging site where decisions are made and physically improved [64]. Figure 3 describes the practical approaches of the wireless sensor network mounted on the field. In this framework, farmers can obtain information in real-time (soil moisture and crop growth) through SMS facility or some android application for their area to get better management practices and crop yield. By utilizing this information, farmers can get updates about the farmland and nursery and could be opined about when and how much water is needed for irrigation practices. Automatic irrigation systems or nursery irrigation systems permit farmers to give or supply the right time of 


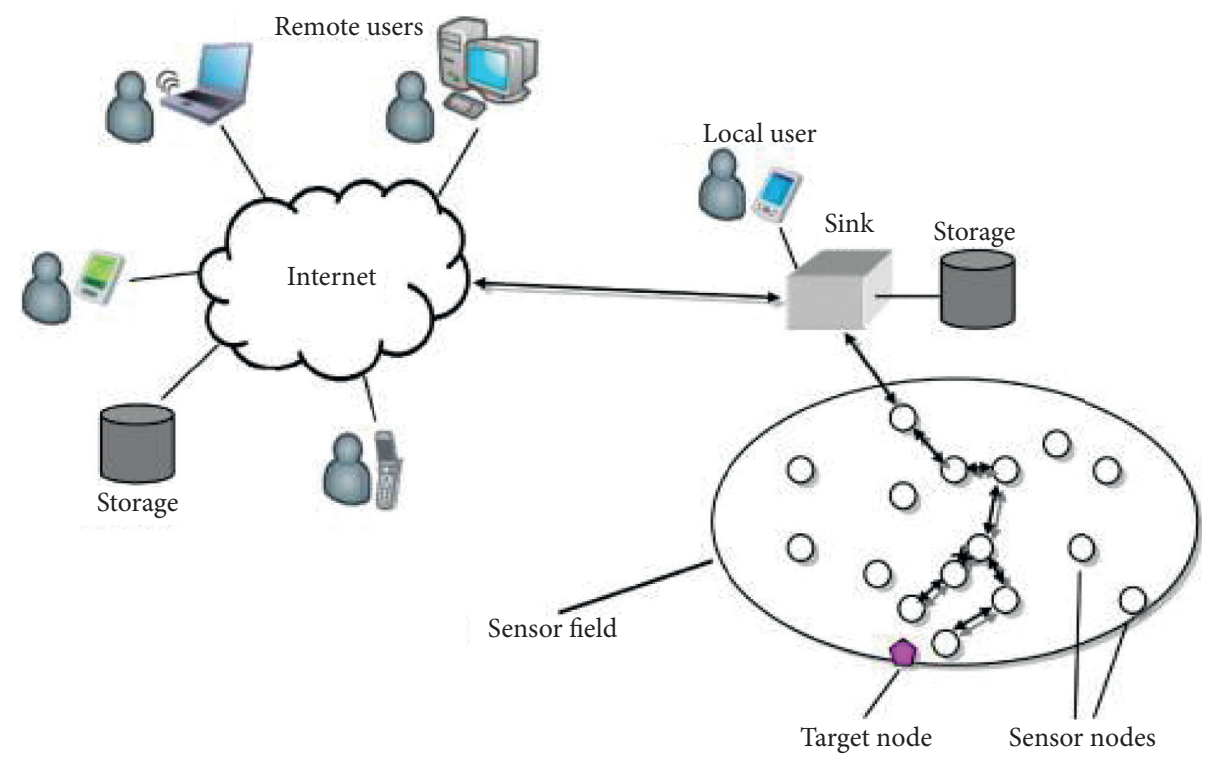

FIgURE 3: Sensor network application in field source [67].

water with the right amount. This system also allows the farm manager to maintain the moisture level concerning time. Some studies proved that if we apply the water at the right time and right amount, the productions can be increased up to $25 \%$ to $30 \%[65,66]$.

3.3. Wireless Signal Communication in Irrigation Systems. Various designs and architectures were proposed for plugand-play technology to measure the soil moisture and develop the sprinkler valve controller for site-specific irrigation automation and management through distributed sensor network. Wall et al. stated that data arrangement and control management are the most effective techniques to manage all the data using low-cost microcontrollers. However, it is challenging to set the sensing stations on the field to connect base stations with wires because of station maintenance, labor cost, and considerable distance, especially more than $10 \mathrm{~m}$. Wires systems are not very much feasible because cables are damaged by farm equipment and animals. That is why wireless networks develop grate intentions nowadays and avoid many of these problems and provide easy replacement of broadcast stations. Different wireless technologies are often used in much sensor-based research work, i.e., Wi-Fi, Bluetooth, and ZigBee [68]. A detailed assessment of different sensor-based technology is discussed in Table 5. ZigBee wireless sensors are the low-cost and lowerpower-consumption technology that is mostly used to develop the wireless sensor network over different techniques. It was established in May 2003, and ISM (industrial scientific and medical) bands are used to operate, i.e., $2.4 \mathrm{GHz}$, globally.

For integrating sensors and actuators, there are some control standards for RS485 (current based) and RS232 (voltage base) wireless protocol that have been widely applied and well documented in some industrial application. Bluetooth and ZigBee (IEEE 802.11 standards) are designed for radio frequency of cell phone applications that require insufficient data, proper network security, and long battery life [69]. Kim et al. stated that ZigBee is a low-cost wireless networking system with advanced features; they provide high reliability due to its direct-sequence (DS/SS) and mesh networking systems. ZigBee technology is cheaper and reliable than Bluetooth, and it can also be used to ensure the integrity and to avoid interference. ZigBee not only requires deficient power than Bluetooth but can also transmit effectively over less distance (e.g., $30 \mathrm{~m}$ ). Advanced wireless transmitters are accessible that are operated with Bluetooth and communicate up to $1 \mathrm{~km}$. Mostly in the agriculture sector, these types of wireless technologies are connected to control and sense the field condition $[70,71]$.

\section{Description of the Data Acquisition System for the Specific Field}

A total of three sensors, including a air temperature and humidity sensor, a light intensity sensor, and a soil moisture sensor, were used for the assessment of any particular area to capture four environmental parameters, namely, temperature, humidity, surrounding light intensity, and soil moisture content. The data collection method provides the opportunity to assess the ecological conditions in the agricultural sector accurately. Also, the system's versatility allows additional monitors, including a $\mathrm{pH}$ sensor, to estimate plant nutrients, a UV sensor to determine ultraviolet light intensity, greenhouse gases and pressure sensor to track the ambient air composition, a rain sensor is used to detect rainy weather, and a water level sensors used to identify flood in the region, and these are included in the system according to client requirement. The module was used to read the surrounding environment captured by the sensors and process the data, and wireless communication transmits the data to the cloud server over the network system. Vital information from all agricultural fields was gathered and 
TABLE 5: Communication technologies in modern irrigation.

\begin{tabular}{lcccc}
\hline Parameters & Bluetooth & ZigBee & Wibree & WIFI \\
\hline Data rate power consumption & $1 \mathrm{Mbps}$ medium & $250 \mathrm{kbps}$ low & $1 \mathrm{mbps}$ low & $13-56 \mathrm{high}$ \\
Range of frequency band & $2.5 \mathrm{GHz}(35-3500 \mathrm{ft})$ & $2.4 \mathrm{GHz}(30-1.6 \mathrm{~m})$ & $2.5 \mathrm{GHz}$ up to $10 \mathrm{ft}$ & $2.5 \mathrm{GHz}(100-150 \mathrm{ft})$ \\
Security & 64 or $128 \mathrm{bits}$ & $128 \mathrm{bits}$ & 128 bits & High CCK/DSSS, OFDM \\
Cost modulation & Low FHSS & Low DSSS, CA/CSMA & Low FHSS & High \\
\hline
\end{tabular}

processed on the cloud server, as shown in Figure 4. The irrigation surveillance system established for this assessment is cost-effective and highly interactive and can be easily adapted to any agricultural field using the plug-and-play technique. This system is also operated by solar energy, rendering individual data acquisition units entirely wireless and portable, thus eliminating the need for cabling for power supply and data transmission, leading to reduce installation, maintenance, and relocation costs.

4.1. On-Site and Functionality Analysis. The sprinkler irrigation system was designed for wheat crop for an area of 1 acre. The total area was divided into four plots, each part consisting of a rain gun. The device has been tested to ensure that environmental data can be collected via sensors; the information can be transmitted to the IoT platform through an online website. The machine has been running for a few minutes to get several data entries. Sprinkler field has been divided into four plots, and soil moisture sensors have been mounted in each location. This test was conducted to ensure that the device can perform as required under real-world daily usage conditions. The prototype and layout of the data acquisition unit were switched on and staked into the ground of the research field, as shown in Figure 5. All four plots were atomized by connecting them through $\mathrm{Wi}-\mathrm{Fi}$ networking. An on-site website was developed, which gives the current soil moisture readings of all the sensors installed in the field and save the recorded data. Sensor stand, board circuits, and continuous electric supply were managed using an uninterruptible power supply.

The system was able to capture broadcast and environmental data as designed successfully. The light intensity sensors were also closed as the water was poured into the soil to simulate a change in environmental conditions. The computer was able to detect these changes without any problems, as shown in Figure 6. All tested fields were atomized once again by connecting them through a Wi-Fi network. An on-site website was also devolved, which gives the current soil moisture readings of all the sensors installed in the field and saves the recorded data. An account on Thing Speak was also made to make graphs of the recorded data. Sensor stand, board circuits, and continuous electric supply were managed using an uninterruptible power supply. Moreover, one point of contention during the prototype test was the wireless connectivity range. As this test was carried out by linking a prototype signal processing unit to a $\mathrm{Wi}-\mathrm{Fi}$ network established by a Wi-Fi hotspot from a cell phone, the device would lose its connection and stop transmitting information to the IoT platform if it moved approximately $5 \mathrm{~m}$ apart from the user. This problem could be overcome by

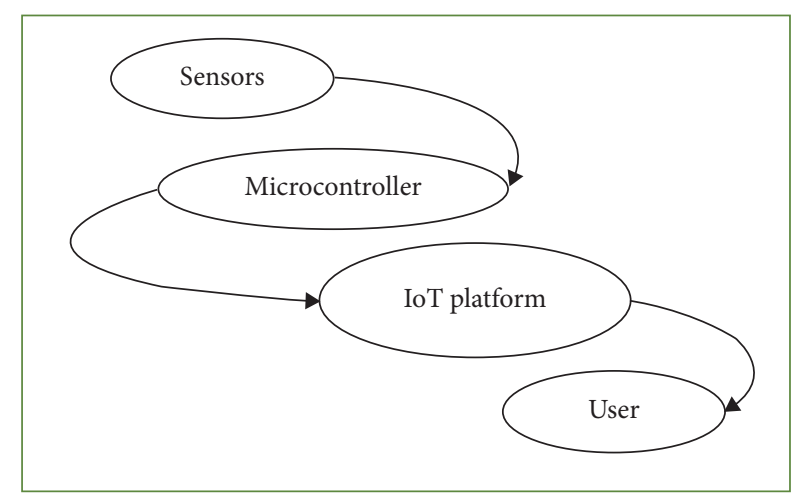

FIGURE 4: Block diagram of the agriculture monitoring system.

installing wireless access points (WAPs) throughout the field via the wireless local area network (WLAN) since this is the primary form of wireless connectivity for the full-scale implementation of the device. One WAP implementation will provide an enhanced wireless network range of up to $0.5 \mathrm{~km}$. This system facilitated to improve the labor efficiency, water productivity, and water use efficiency in cereal crops (i.e., wheat and maize) and saved water about $44 \%$ in the case of a sprinkler irrigation system. It was also concluded that 20 feet border treatment was better treatment than other treatments as agronomic results were better for this treatment, and cutoff distance must be between 60 and 70 percent of total length. Based on wireless sensor network systems, different opportunities must have been created for existing application areas that require real and remote sensing data for observing consequences. However, these tools have possessed many problems that must be solved for a long-time variability of the proposed system. Different issues like more energy are required for operating sensors nodes, development issues containing communication, deployment, and protocols. The problems in wireless networks were discussed in the previous work $[22,72]$ and have been addressed to a solution $[73,74]$. There are some possibilities that strong wind also creates some problem in the sensor so there should be robust fitting around the sensors to support the nodes. The advantages and disadvantages of (WSN) in sensor-based irrigation are discussed in Table 6 .

4.2. Advantages of Automated Sprinkler Irrigation. The primary objective of automated sprinkler irrigation is to supply a minimum amount of irrigation water throughout the fields. Sensor-based irrigation has a significant potentiation to save water and increase economic efficiencies. The main advantage of this system is to reduce the input cost or 


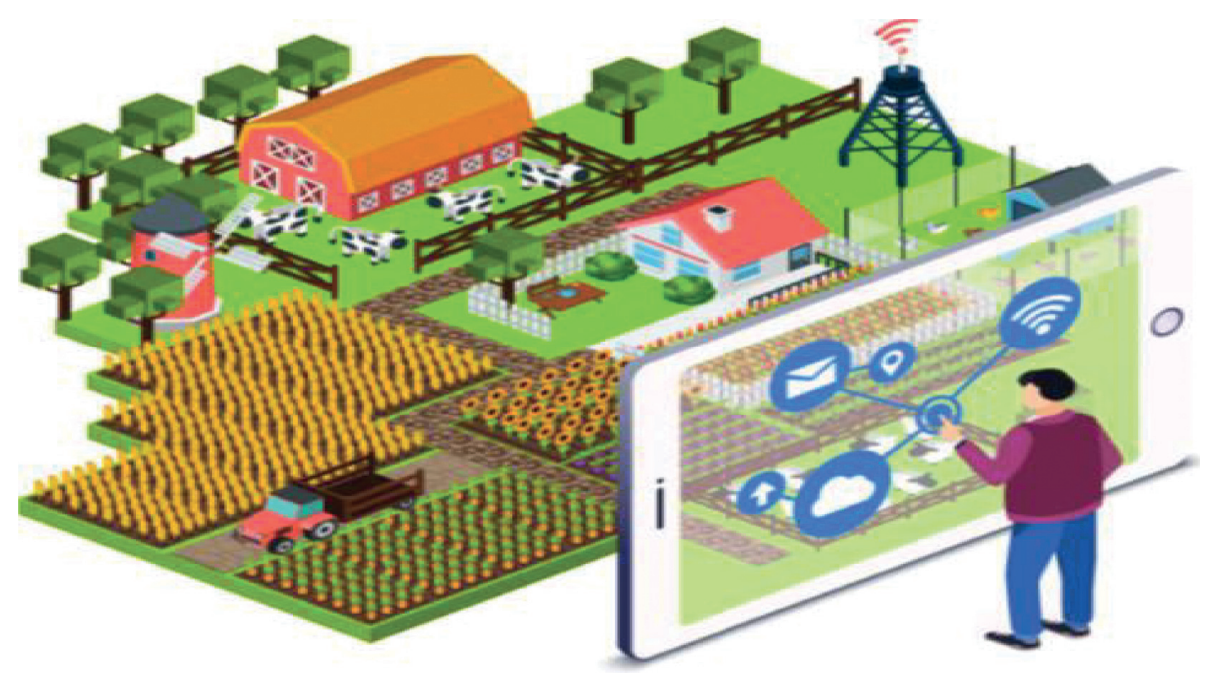

(a)

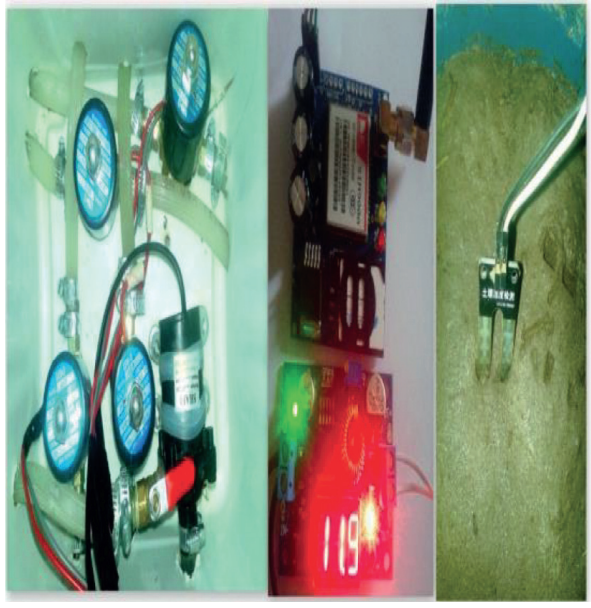

(b)

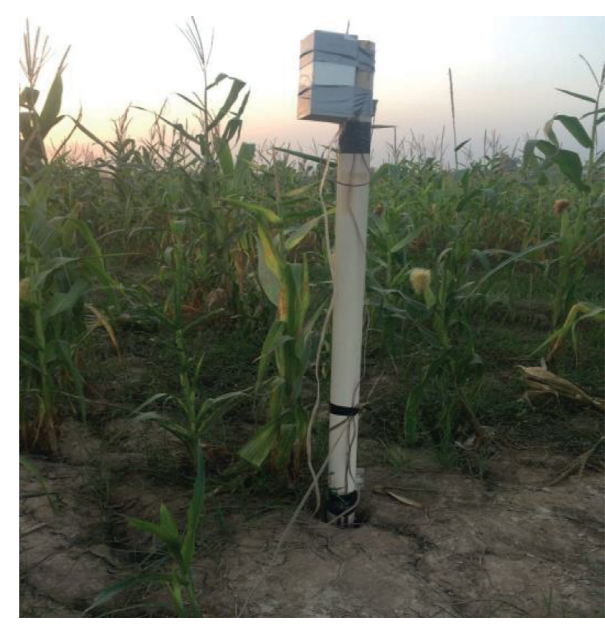

(c)

FIGURE 5: On-site test for automated irrigation: (a) layout sketch; (b) solenoid valves, GSM module, and moisture sensor; (c) installed moisture sensor.

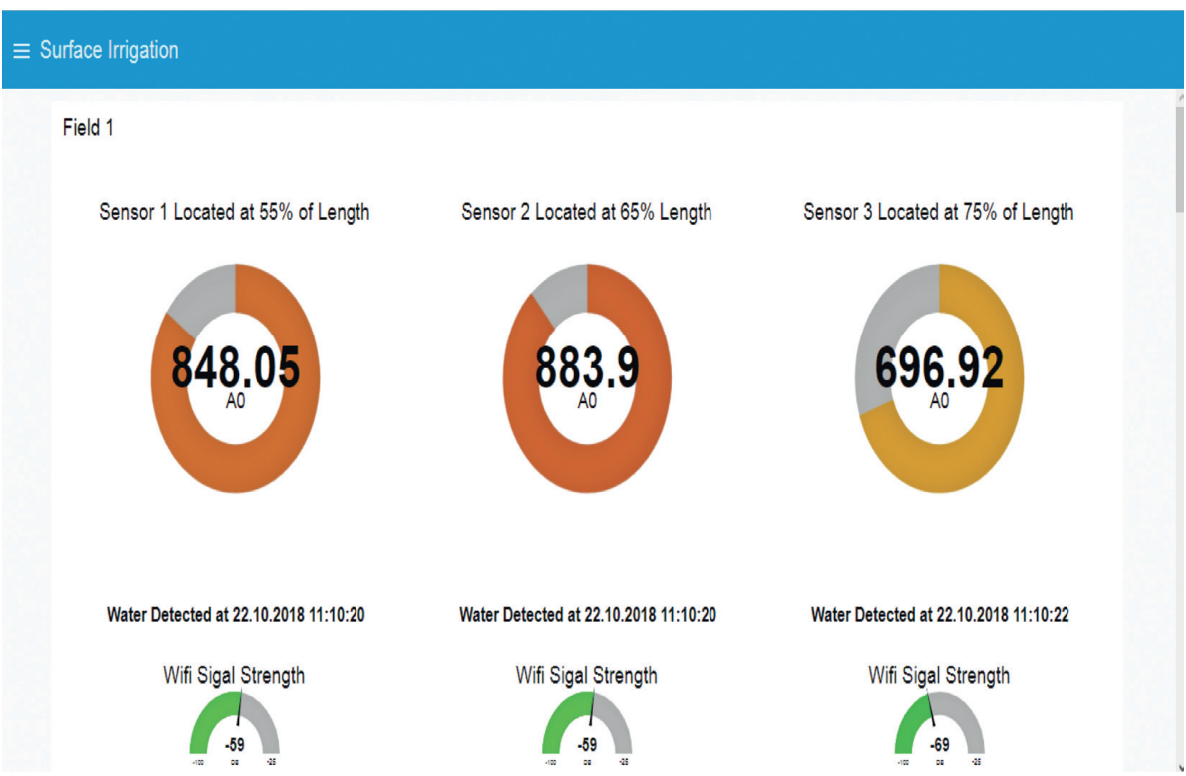

Figure 6: On-site analysis data on IoT platform. 
TABLE 6: Advantages and disadvantages of wireless sensor network.

\begin{tabular}{lc}
\hline Advantages & Disadvantages \\
\hline $\begin{array}{l}\text { Provides dynamic navigation and easy to move and replace stations } \\
\text { Allows farmers to maximize their productivity during conservation of water }\end{array}$ & Energy consumption for autonomous \\
Network data are used to manage the sensors and microcontrollers are available in less amount & Small memory and data security \\
The effectiveness of the sensor depends on the control coordination and instrumentation data & Interference by vegetation \\
\hline
\end{tabular}

to increase the yield for the same input. With this irrigation technology, the human intervention must be minimized. With the automated technology of irrigation, human intervention can be reduced $[75,76]$. Some advantages of this innovation can be discussed as follows.

4.2.1. Water-Saving Technology. Many researchers have been reported that the intelligence irrigation method is the ideal possible method of accomplishing significant water saving [77]. Muñoz-Carpena and Dukes stated that sprinkler irrigation with sensor applications could improved the water efficiency up to $80-90 \%$ as against $40-45 \%$ in the surface irrigation method [78]. Blomquist et al. [62] concluded that $16 \%$ of water could be saved in this irrigation practice.

4.2.2. System Cost. The irrigation system is developed with the module design, which helped a lot to reduce the cost. The wireless sensor node and actuator node were about 30 US dollars, and the portable controller was around $\$ 100$. The total cost to build up a wireless field irrigation system depended on the planting area, and for a case of $5000 \mathrm{~m}^{2}$, it was approximately $\$ 500$ in terms of hardware cost.

4.2.3. Profit and Yield. Proper timing of irrigation is stated to be a critical factor in production while delaying irrigation can result in losses of between US\$ 62/ha and US\$ 300/ha. [79]. El-Kader and El-Basioni conducted an experiment on [67] potato yield measured in Egypt using sensor-based network technology. It has been confirmed that yields have improved, and a loss of 2 billion pounds has been recovered in a year. Due to these reasons, the quality of water used is reduced and the distribution of water is not optimized. Farmers irrigate their fields based on their traditional information without worrying about soil moisture levels, soil quality, crop water requirements, and weather forecasting.

4.3. Control Options of Sprinkler Mechanism. During irrigation, the event control system is responsible for regulating the speed of sprinkler systems multiple times and also moves the sprinkler position at $360^{\circ}$ of the field, where the rate will be changed and decision about more lees or no irrigation water is taken. This phenomenon would be used where different crops are planted in the same field [80,81]. A series of the on-off cycle can be used to accomplish the water depth application for the individual sprinkler control system $[82,83]$. Adjusting the traveling speed of the center pivot sprinkler system is the most basic method to measure the water depth against field topographic, soil condition, and different crops. The primary function of center pivot systems is to irrigate the land from one point in a circle and work on the different topography regions having a range in soil textures present under a single machine. So that these factors are the main reasons to use the controller to manage the water application in the field based upon the need. Sitespecific irrigation and variable rate irrigation are the main terms that describe the water applications devises in order to maximize the yield and economical value for irrigation water applied through different moving systems [84, 85]. Chavez et al. reported that, for better performance of remote irrigation systems, control and monitoring systems are fixed on two different lined moves. A series of in-field and onboard wireless sensor networks are used to verify the precision irrigation systems with high accuracy. Separate nozzle regulators were pounded according to sanction maps $[86,87]$. Various manifolds attached with different sizes of sprinkler nozzles should be used for accomplishing and controlling irrigation water application depth to fluctuate water and nitrogen application $[88,89]$. Usually, open solenoids were attached with systems to allow the insurance to supply the irrigation water even when control systems failed. For controlling irrigation water application, a variable flow sprinkler was developed by King and Kincaid [90] and Liu et al. [91]. It used the activated pin, which is operated mechanically to regulate the orifice area of nozzle and mainly it depends on operating pressure, and the flow rate of the sprinkler is adjusted within the range of $35 \%$ to $100 \%$. Hydraulic or electric actuators were used to control the pin. The main problem is that the droplet size distribution and the wetted pattern are changed with flow rate and create a uniformity issue with overlapping of the sprinkler pattern [92, 93]. 2-3 manifolds were used in these systems, which serve to maintain the depth of water and water application rate.

\section{Summary and Conclusion}

The objective of this research work was to highlight the development of improved agricultural monitoring systems that address problems of existing plans, including price, availability, and outdoor accessibility. A simple, low-cost, sustainable agricultural control system that is extremely customizable and reliable for outdoor use, self-powered to reduce the need for long power supply cables, while providing better functionality that helps to reduce the agricultural burden and promotes crop yields and income, has been developed. In semiarid regions of emerging countries, small farmers and marginal farmers (who have land b/w 4 and 6 hectares) are facing many problems regarding powered irrigation. Most of the time, they are relying on seasonal precipitation for their productivity. The data analysis unit 
composed of sensors and integrated circuits may successfully capture the physiological conditions such as temperature, humidity, light density, and soil water content. These data are vital for field managers to manage resources, develop predictive crop growth models, and automate farm machinery. This contributes to successful agriculture activities, and resource use decreased the operational costs and workloads and increased the crop productivity. The WSN system built in this study offers an enhanced monitoring range. The intelligent sensor-based irrigation system work has been discussed in this review paper, controlling the different irrigation management practices by sensing different agriculture parameters such as soil moisture, soil $\mathrm{pH}$, humidity, and temperature. These systems allow farmers to monitor and control their farmland with user friendly mobile applications. The sensor-based irrigation protects water pumps against any harmful damages by controlling and monitoring water pressure and input voltage. Demands for sensor-based irrigation increase day by day and have a substantial future scope. It is time-saving and also removes the human error by controlling soil moisture levels. The development of sensor-based applications in agriculture makes it possible to increase the productivity, efficiency, and profitability through precision agriculture farming.

\section{Data Availability}

No data are used to support the study.

\section{Conflicts of Interest}

The authors declare no conflicts of interest.

\section{Authors' Contributions}

All authors significantly contributed to the scientific study and writing. Wei Li. and Weidong Shi were involved in the conceptualization; Muhammad Awais was involved in the methodology and software; Saad Uddin curated the data; Chenchen Liu and Muhammad Awais wrote and prepared the original draft; Weimin Ru, Muhammad Ajmal, and Saad Uddin wrote, reviewed, and edited the manuscript; Wei Li supervised the study.

\section{Acknowledgments}

The work was sponsored by the Synergistic Innovation Center of Jiangsu Modern Agriculture Equipment and Technology (No.4091600014).

\section{References}

[1] P. K. Thornton, P. Kristjanson, W. Förch, C. Barahona, L. Cramer, and S. Pradhan, "Is agricultural adaptation to global change in lower-income countries on track to meet the future food production challenge?" Global Environmental Change, vol. 52, pp. 37-48, 2018.

[2] R. Sonnino, C. L. S. Tegoni, and A. De Cunto, "The challenge of systemic food change: insights from cities," Cities, vol. 85, pp. 110-116, 2019.
[3] W. S. de Amorim, A. Borchardt Deggau, G. do Livramento Gonçalves, S. da Silva Neiva, A. R. Prasath, and J. B. Salgueirinho Osório de Andrade Guerra, "Urban challenges and opportunities to promote sustainable food security through smart cities and the 4th industrial revolution," Land Use Policy, vol. 87, Article ID 104065, 2019.

[4] F. A. Abdullah and B. A. Samah, "Factors impinging farmers' use of agriculture technology," Asian Social Science, vol. 9, no. 3, p. 120, 2013.

[5] D. Blandford, J. Braden, and J. S. Shortle, "Economics of natural resources and environment in agriculture," in Agriculture and the Environment, pp. 18-34, Elsevier, Amsterdam, Netherlands, 2014.

[6] G. E. Eckstein, "Water scarcity, conflict, and security in a climate change world: challenges and opportunities for international law and policy," Wisconsin International Law Journal, vol. 27, p. 409, 2009.

[7] N. Sharma, Youths Perception for Agricultural Enterpreneurship: A Case Study of Tehsil Karsog in Himachal Pradesh, Department of Business Management College of Horticulture, Dr. Yashwant Singh Parmar University of Horticulture and Forestry, Nauni, India, 2016.

[8] T. X. Cuong, H. Ullah, A. Datta, and T. C. Hanh, "Effects of silicon-based fertilizer on growth, yield and nutrient uptake of rice in tropical zone of Vietnam," Rice Science, vol. 24, no. 5, pp. 283-290, 2017.

[9] P. Deshpande, A. Damkonde, and V. Chavan, "The internet of things: vision, architecture and applications," International Journal of Computer Applications, vol. 178, no. 2, pp. 1-14, 2017.

[10] X. Liu, X. Zhu, Q. Zhang, T. Yang, Y. Pan, and P. Sun, “A remote sensing and artificial neural network-based integrated agricultural drought index: index development and applications," Catena, vol. 186, Article ID 104394, 2020.

[11] A. Evans, The Feeding of the Nine Billion. Global Food Security for the 21st Century, Chatham House, London, UK, 2009.

[12] J. Gubbi, R. Buyya, S. Marusic, and M. Palaniswami, "Internet of Things (IoT): a vision, architectural elements, and future directions," Future Generation Computer Systems, vol. 29, no. 7, pp. 1645-1660, 2013.

[13] M. Mahbub, "A smart farming concept based on smart embedded electronics, internet of things and wireless sensor network," Internet of Things, vol. 9, Article ID 100161, 2020.

[14] L. Xin, L. Guang, and Y. Ming, "Design on the precise regulating control system for moisture and nutrient of plants based on PLC," Physics Procedia, vol. 33, pp. 429-436, 2012.

[15] N. Zhang, M. Wang, and N. Wang, "Precision agriculture-a worldwide overview," Computers and Electronics in Agriculture, vol. 36, no. 2-3, pp. 113-132, 2002.

[16] S. Pallavi, J. D. Mallapur, and KY. Bendigeri, "Remote sensing and controlling of greenhouse agriculture parameters based on IoT," in Proceedings of the 2017 International Conference on Big Data, IoT and Data Science (BID), December 2017.

[17] Q. Chen and T. Chen, "Estimation of river basin evapotranspiration over complex terrain using NOAA AVHRR data," Acta Geographica Sinica, vol. 48, no. 1, pp. 61-69, 1993.

[18] O. Körner and G. Van Straten, "Decision support for dynamic greenhouse climate control strategies," Computers and Electronics in Agriculture, vol. 60, no. 1, pp. 18-30, 2008.

[19] M. Kacira, S. Sase, L. Okushima, and P. P. Ling, "Plant response-based sensing for control strategies in sustainable 
greenhouse production," Journal of Agricultural Meteorology, vol. 61, no. 1, pp. 15-22, 2005.

[20] A. Srinivasan, Handbook of Precision Agriculture: Principles and Applications, CRC Press, Boca Raton, FL, USA, 2006.

[21] C. Ceken, "An energy efficient and delay sensitive centralized MAC protocol for wireless sensor networks," Computer Standards \& Interfaces, vol. 30, no. 1-2, pp. 20-31, 2008.

[22] I. F. Akyildiz, W. Su, Y. Sankarasubramaniam, and E. Cayirci, "A survey on sensor networks," IEEE Communications Magazine, vol. 40, no. 8, pp. 102-114, 2002.

[23] K. Patil and N. Kale, "A model for smart agriculture using IoT," in Proceedings of the 2016 International Conference on Global Trends in Signal Processing, Information Computing and Communication (ICGTSPICC), IEEE, Jalgaon, India, December 2016.

[24] S. Prathibha, A. Hongal, and M. Jyothi, "IoT based monitoring system in smart agriculture," in Proceedings of the 2017 International Conference on Recent Advances in Electronics and Communication Technology (ICRAECT), IEEE, Bangalore, India, March 2017.

[25] G. Sushanth and S. Sujatha, "IOT based smart agriculture system," in Proceedings of the 2018 International Conference on Wireless Communications, Signal Processing and Networking (WiSPNET), IEEE, Chennai, India, March 2018.

[26] D. Davcev, "IoT agriculture system based on LoRaWAN," in Proceedings of the 2018 14th IEEE International Workshop on Factory Communication Systems (WFCS), June 2018.

[27] A. Z. Abbasi, N. Islam, and Z. A. Shaikh, "A review of wireless sensors and networks' applications in agriculture," Computer Standards \& Interfaces, vol. 36, no. 2, pp. 263-270, 2014.

[28] A. R. Roselin and A. Jawahar, "Smart agro system using wireless sensor networks," in Proceedings of the 2017 International Conference on Intelligent Computing and Control Systems (ICICCS), IEEE, Madurai, India, June 2017.

[29] B. Kavitha, "Agricultural crop monitoring sensors using IoT-a study," in Proceedings of the 2017 11th International Conference on Intelligent Systems and Control (ISCO), Coimbatore, India, January 2017.

[30] A. H. Abbas, M. M. Mohammed, G. M. Ahmed, E. A. Ahmed, and R. A. Abdel Azeem Abul Seoud, "Smart watering system for gardens using wireless sensor networks," in Proceedings of the 2014 International Conference on Engineering and Technology (ICET), April 2014.

[31] M. M. Ahmed, E. Ahmed, and K. T. Ahmmed, “Automated irrigation control and security system with wireless messaging," in Proceedings of the 2013 International Conference on Informatics, Electronics and Vision (ICIEV), May 2013.

[32] X. Han, "Development of a low-cost GPS/INS integrated system for tractor automatic navigation," International Journal of Agricultural and Biological Engineering, vol. 10, no. 2, pp. 123-131, 2017.

[33] F. Kang, "An automated trailer sprayer system for targeted control of cutworm in vineyards," Transactions of the ASABE, vol. 54, no. 4, pp. 1511-1519, 2011.

[34] X. Zhu, "Review of intelligent sprinkler irrigation technologies for remote autonomous system," International Journal of Agricultural \& Biological Engineering, vol. 11, no. 1, pp. 23-30, 2018.

[35] D. J. Mulla, "Twenty five years of remote sensing in precision agriculture: key advances and remaining knowledge gaps," Biosystems Engineering, vol. 114, no. 4, pp. 358-371, 2013.

[36] J. Piekarczyk, "Application of remote sensing in agriculture," Geoinformatica Polonica, vol. 13, no. 1, pp. 69-75, 2014.
[37] Y. Fenghua, X. Tongyu, D. Wen et al., "Radiative transfer models (RTMs) for field phenotyping inversion of rice based on UAV hyperspectral remote sensing," International Journal of Agricultural and Biological Engineering, vol. 10, no. 4, pp. 150-157, 2017.

[38] Q. Liang, "A cross-layer transmission scheduling scheme for wireless sensor networks," Computer Communications, vol. 30, no. 14-15, pp. 2987-2994, 2007.

[39] J. Gutiérrez, J. F. Villa-Medina, A. Nieto-Garibay, and M. A. Porta-Gandara, "Automated irrigation system using a wireless sensor network and GPRS module," IEEE Transactions on Instrumentation and Measurement, vol. 63, no. 1, pp. 166-176, 2014.

[40] J. B. Lamb, J. A. J. M. van de Water, D. G. Bourne et al., "Seagrass ecosystems reduce exposure to bacterial pathogens of humans, fishes, and invertebrates," Science, vol. 355, no. 6326, pp. 731-733, 2017.

[41] G. Richard, FAO Irrigation and Drainage Paper, Food and Agriculture Organization, Rome, Italy, 2006.

[42] E. F. B. Poyen, "Irrigation-an automated design proposal," in Proceedings of the International conference on Innovative Engineering Technologies (ICIET'2014), Bangkok, Thailand, December 2014.

[43] G. H. Hargreaves and Z. A. Samani, "Reference crop evapotranspiration from temperature," Applied Engineering in Agriculture, vol. 1, no. 2, pp. 96-99, 1985.

[44] C. Jones, "Crop growth models," in Management of Farm Irrigated Systems, St. Joseph, MN, USA, 1990.

[45] M. Cobaner, "Evapotranspiration estimation by two different neuro-fuzzy inference systems," Journal of Hydrology, vol. 398, no. 3-4, pp. 292-302, 2011.

[46] L. Ruiz-Garcia, L. Lunadei, P. Barreiro, and I. Robla, “A review of wireless sensor technologies and applications in agriculture and food industry: state of the art and current trends," Sensors, vol. 9, no. 6, pp. 4728-4750, 2009.

[47] M. Dursun and S. Ozden, "A wireless application of drip irrigation automation supported by soil moisture sensors," Scientific Research and Essays, vol. 6, no. 7, pp. 1573-1582, 2011.

[48] T. Kalaivani, A. Allirani, and P. Priya, "A survey on Zigbee based wireless sensor networks in agriculture," in Proceedings of the 3rd International Conference on Trendz in Information Sciences \& Computing (TISC2011), December 2011.

[49] S. S. Mathurkar and D. Chaudhari, "A review on smart sensors based monitoring system for agriculture," International Journal of Innovative Technology and Exploring Engineering (IJITEE) ISSN, vol. 2, no. 4, 2013.

[50] R. G. Vishwakarma and V. Choudhary, "Wireless solution for irrigation in agriculture," in Proceedings of the 2011 International Conference on Signal Processing, Communication, Computing and Networking Technologies, July 2011.

[51] S. Prasad and L. M. Bruce, "A divide-and-conquer paradigm for hyperspectral classification and target recognition," in Optical Remote Sensing., pp. 99-122, Springer, Berlin, Germany, 2011.

[52] M. C. Anderson, C. Hain, J. Otkin et al., "An intercomparison of drought indicators based on thermal remote sensing and NLDAS-2 simulations with U.S. drought monitor classifications," Journal of Hydrometeorology, vol. 14, no. 4, pp. 1035-1056, 2013.

[53] B. Stark, B. Smith, and Y. Chen, "Survey of thermal infrared remote sensing for Unmanned aerial systems," in Proceedings of the 2014 International Conference on Unmanned Aircraft Systems (ICUAS), May 2014. 
[54] S. Khanal, J. Fulton, and S. Shearer, "An overview of current and potential applications of thermal remote sensing in precision agriculture," Computers and Electronics in Agriculture, vol. 139, pp. 22-32, 2017.

[55] D. A. Quattrochi and J. C. Luvall, "Thermal infrared remote sensing for analysis of landscape ecological processes: methods and applications," Landscape Ecology, vol. 14, no. 6, pp. 577-598, 1999.

[56] W. De-Cai, G.-L. Zhang, X.-Z. Pan, Y.-G. Zhao, M.-S. Zhao, and G.-F. Wang, "Mapping soil texture of a plain area using fuzzy-c-means clustering method based on land surface diurnal temperature difference," Pedosphere, vol. 22, no. 3, pp. 394-403, 2012.

[57] G. D. Abowd, "Towards a better understanding of context and context-awareness," in International Symposium on Handheld and Ubiquitous ComputingSpringer, Berlin, Germany, 1999.

[58] B. N. Schilit and M. M. Theimer, "Disseminating active map information to mobile hosts," IEEE Network, vol. 8, no. 5, pp. 22-32, 1994.

[59] B. King, R. Wall, and L. Wall, Supervisory Control and Data Acquisition System for Closed-Loop Center Pivot Irrigation, American Society of Agricultural and Biological Engineers, St. Joseph, MI, USA, 2000.

[60] S. Jin, S. Jingling, H. Qiuyan, W. Shengde, and Y. Yan, "A remote measurement and control system for greenhouse based on GSM-SMS," in Proceedings of the 2007 8th International Conference on Electronic Measurement and Instruments, August 2007.

[61] N. T. Son, C. F. Chen, C. R. Chen, L. Y. Chang, H. N. Duc, and L. D. Nguyen, "Prediction of rice crop yield using MODIS EVI-LAI data in the Mekong Delta, Vietnam," International Journal of Remote Sensing, vol. 34, no. 20, pp. 7275-7292, 2013.

[62] J. Blonquist Jr., S. B. Jones, and D. Robinson, "Precise irrigation scheduling for turfgrass using a subsurface electromagnetic soil moisture sensor," Agricultural Water Management, vol. 84, no. 1-2, pp. 153-165, 2006.

[63] S. U. Susha Lekshmi, D. N. Singh, and M. Shojaei Baghini, “A critical review of soil moisture measurement," Measurement, vol. 54, pp. 92-105, 2014.

[64] C. Shock, "Innovative, automatic, low-cost reading of watermark soil moisture sensors," in Proceedings of the 1999 Irrigation Association Technical Conference, Falls Church, VA, USA, 1999.

[65] P. Berk, M. Hocevar, D. Stajnko, and A. Belsak, "Development of alternative plant protection product application techniques in orchards, based on measurement sensing systems: a review," Computers and Electronics in Agriculture, vol. 124, pp. 273-288, 2016.

[66] H. Van Luu and X. Tang, "An efficient algorithm for scheduling sensor data collection through multi-path routing structures," Journal of Network and Computer Applications, vol. 38, pp. 150-162, 2014.

[67] S. M. A. El-Kader and B. M. M. El-Basioni, "Precision farming solution in Egypt using the wireless sensor network technology," Egyptian Informatics Journal, vol. 14, no. 3, pp. 221-233, 2013.

[68] R. W. Wall and B. A. King, "Incorporating plug and play technology into measurement and control systems for irrigation management," in Proceedings of the 2004 ASAE Annual Meeting. 2004, American Society of Agricultural and Biological Engineers, Ottawa, Canada, August 2004.

[69] C. M. G. Pedras, L. S. Pereira, and J. M. Gonçalves, "MIRRIG: a decision support system for design and evaluation of microirrigation systems," Agricultural Water Management, vol. 96, no. 4, pp. 691-701, 2009.

[70] Y. Kim, R. G. Evans, and W. M. Iversen, "Remote sensing and control of an irrigation system using a distributed wireless sensor network," IEEE Transactions on Instrumentation and Measurement, vol. 57, no. 7, pp. 1379-1387, 2008.

[71] Y. Kim and R. G. Evans, "Software design for wireless sensorbased site-specific irrigation," Computers and Electronics in Agriculture, vol. 66, no. 2, pp. 159-165, 2009.

[72] A. Willig, "Wireless sensor networks: concept, challenges and approaches," E \& I Elektrotechnik und Informationstechnik, vol. 123, no. 6, pp. 224-231, 2006.

[73] G. Anastasi, M. Conti, M. Di Francesco, and A. Passarella, "Energy conservation in wireless sensor networks: a survey," Ad Hoc Networks, vol. 7, no. 3, pp. 537-568, 2009.

[74] S. Ozdemir and Y. Xiao, "Secure data aggregation in wireless sensor networks: a comprehensive overview," Computer Networks, vol. 53, no. 12, pp. 2022-2037, 2009.

[75] K. Kansara, "Sensor based automated irrigation system with IOT: a technical review," International Journal of Computer Science and Information Technologies, vol. 6, no. 6, 2015.

[76] H. Li, Z. Issaka, Y. Jiang, P. Tang, and C. Chen, "Overview of emerging technologies in sprinkler irrigation to optimize crop production," International Journal of Agricultural and Biological Engineering, vol. 12, no. 3, pp. 1-9, 2019.

[77] N. Shah and I. Das, Precision Irrigation Sensor Network Based Irrigation. Problems, Perspectives and Challenges of Agricultural Water Management, InTech, Rijeka, Croatia, 2012.

[78] R. Muñoz-Carpena and M. D. Dukes, "Automatic irrigation based on soil moisture for vegetable crops," Nutrient Management of Vegetable and Row Crops Handbook, p. 173, University of Florida, Gainesville, FL, USA, 2015.

[79] G. Vellidis, M. Tucker, C. Perry, C. Kvien, and C. Bednarz, “A real-time wireless smart sensor array for scheduling irrigation," Computers and Electronics in Agriculture, vol. 61, no. 1, pp. 44-50, 2008.

[80] X. Zhu, S. Yuan, J. Jiang, J. Liu, and X. Liu, "Comparison of fluidic and impact sprinklers based on hydraulic performance," Irrigation Science, vol. 33, no. 5, pp. 367-374, 2015.

[81] F. A. Dwomoh, Y. Shouqi, and L. Hong, "Field performance characteristics of fluidic sprinkler," Applied Engineering in Agriculture, vol. 29, no. 4, pp. 529-536, 2013.

[82] D. Karmeli and G. Peri, "Basic principles of pulse irrigation," Journal of the Irrigation and Drainage Division, vol. 100, no. 3, pp. 309-319, 1974.

[83] W. Yaxiong, "Identification and location of grapevine sucker based on information fusion of 2D laser scanner and machine vision," International Journal of Agricultural and Biological Engineering, vol. 10, no. 2, pp. 84-93, 2017.

[84] Y. Kim, R. G. Evans, and W. M. Iversen, "Evaluation of closedloop site-specific irrigation with wireless sensor network," Journal of Irrigation and Drainage Engineering, vol. 135, no. 1, pp. 25-31, 2009.

[85] S. Cai, "Photovoltaic optimization of solar-powered linear move sprinkler irrigation system," Journal of Drainage and Irrigation Machinery Engineering, vol. 35, no. 5, pp. 417-423, 2017.

[86] J. L. Chávez, F. J. Pierce, and R. G. Evans, “Compensating inherent linear move water application errors using a variable rate irrigation system," Irrigation Science, vol. 28, no. 3, pp. 203-210, 2010.

[87] J. L. Chávez, F. J. Pierce, T. V. Elliott, and R. G. Evans, “A remote irrigation monitoring and control system for 
continuous move systems. Part A: description and development," Precision Agriculture, vol. 11, no. 1, pp. 1-10, 2010.

[88] C. Camp, E. J. Sadler, D. E. Evans, L. J. Usrey, and M. Omary, "Modified center pivot system for precision management of water and nutrients," Applied Engineering in Agriculture, vol. 14, no. 1, pp. 23-31, 1998.

[89] R. L. Roth and B. R. Gardner, "Modified self-moving irrigation system for water-nitrogen crop production studies," Applied Engineering in Agriculture, vol. 5, no. 2, pp. 175-179, 1989.

[90] B. King and D. Kincaid, "A variable flow rate sprinkler for site-specific irrigation management," Applied Engineering in Agriculture, vol. 20, no. 6, p. 765, 2004.

[91] J. Liu, "Drop size distribution experiments of gas-liquid two phases fluidic sprinkler," Journal of Drainage and Irrigation Machinery Engineering (JDIME), vol. 35, no. 8, pp. 731-736, 2017.

[92] K. Tian, "Development and performance test of lateral move irrigation system," Journal of Drainage and Irrigation Machinery Engineering, vol. 35, no. 4, pp. 357-361, 2017.

[93] J. Wan, "Translocating speed ration effect on water distribution uniformity of lightweight lateral move irrigation system," Water Saving Irrigation, vol. 9, pp. 87-89, 2016. 